\title{
Diverting young offenders from crime in Ireland The need for more checks and balances on the exercise of police discretion
}

\section{Philip Smyth*}

\begin{abstract}
The Irish police (the Garda Síochána) have been exercising their law enforcement discretion to pursue a diversionary strategy for young offenders since at least 1953. Working in a street environment of low visibility they have managed to expand their traditional law enforcement function into territory more appropriately reserved for courts, social workers and probation officers. This article charts the development of this expansion and examines its current manifestation in the juvenile diversion programme. It argues that the welfare benefits for the young offenders are being purchased at the cost of due process rights, and that there is a need for more custom built accountability checks and balances to strike a better balance in the programme.
\end{abstract}

\section{Introduction}

The police have a significant role as the 'gatekeepers' of the juvenile justice system $[11,41,44]$. They are the first point of contact a juvenile offender has with the system. While it is arguable that the treatment of juvenile delinquency is outside the proper remit of the police, there is a general acceptance that the police function encompasses the detection of delinquency and the triggering of the formal treatment process $[28,44,57,69]$. Discretion has a key role to play in this process. The police have traditionally used informal, non-court methods when dealing with very minor offenders. Depending on the nature of the offence, they have always had the option of dealing with the offending youth by means of a caution, rather than initiating a prosecution. The police caution was extended with the introduction of the juvenile liaison scheme which provides a variety of options for dealing with juvenile offenders [36]. Generally, these entail the exercise of broad discretionary powers on a daily basis by officers acting beyond their traditional enforcement function, and in conditions of low visibility. How those discretionary powers are used by the police is an important factor affecting a young person's future [21, 54]. This, in turn, emphasises the importance of appropriate methods of police governance and accountability in juvenile justice. 
This article examines how the current juvenile liaison scheme facilitates the expansion of the police role into territory more appropriately reserved for courts, social workers and probation officers, and the threat that that poses to the due process rights of young offenders. It argues that there is a need for more custom built accountability checks and balances to offset this threat. It begins by outlining key aspects of the manner in which the police managed to usurp judicial and welfare functions in the treatment of young offenders.

\section{The expansion of the police function}

Since the inception of the modern police force up to the early part of the nineteenth century, deviant youths found committing trivial offences were often dealt with informally on the spot and on the street by way of the "constabular rebuke or cuff" [57]. The Metropolitan Police Act of 1839 extended the categories of trivial offences that might attract police attention to include persons found in a "public place flying a kite, playing any game to the annoyance of the inhabitations or passengers, or making a slide in the snow" [40; ss.46,47,49,54]. While the legislation identified the type of offender that a policeman might arrest, it also left the officer considerable discretion to determine whether a person came within one or another or any of the defined categories [37]. This discretion was broad enough to encompass the administration of a caution as an alternative to arrest. Moreover, the occasional police officer would also act outside this discretion form time to time by resorting to the technically unlawful 'clip around the ear, 'the flick of a policeman's rolled cape' or the confiscation of 'toys, marbles or hoops' $[17,45] .{ }^{1}$ Indeed, the first record of a police caution was in 1833, some four years after the establishment of the Metropolitan Police force, and it wasn't until 1853 that official police policy was changed to encourage informal warnings for minor offences [58; pp.54-55].

Prior to 1908 the police were most reluctant to bring juvenile offenders suspected of minor offence, before the ordinary courts, as they were unsuitable for children [37]. Since there were few formal legal distinctions between the trial and punishment of adults and children in those days, the latter would often find themselves in the

\footnotetext{
Teaching Assistant, School of Law, University of Limerick.

${ }^{1}$ According to Denver's Judge Ben B. Lindsey, the foremost juvenile court promoter, the police dealt with boys "based on a doctrine of fear, degradation, and punishment." [35].
} 
company of hardened criminals on remand or in prison. Such an environment had the propensity to ruin childhood innocence through the transmission of adult vices and become a stepping stone to a life of crime [39]. This was compounded by the lengthy pre-trial detention of juveniles, even for very trivial offences. Becker remarked that "one of the most crucial steps in the process of building a stable pattern of deviant behaviour is likely to be the experience of being caught and publicly labelled a deviant" [6; p.31]. The acquisition of a formal criminal record is generally acknowledged to be a critical threshold in the development of delinquency $[6,32$; pp.9-10, 34, 59]. Criminologists who subscribe to this view point to the court appearance as the key event. They see this official intervention as the catalyst or spark that ignites a delinquent career [6, 32; pp.9-10, 34, 59]. Official sanctions also affix negative or stigmatising labels to youthful deviants with predictable negative consequences $[1,6,7,19,29,30,34,55]$. Therefore the longer the offender can be kept away from official intervention, the easier it may be to divert him from a criminal career $[42 ; 49$; para.9.5, 72; 73]. Certainly there is strong evidence for the proposition that:

... juvenile offenders who can be diverted from the criminal justice system at an early stage in their offending are less likely to reoffend than those who become involved in judicial proceedings $[71 ; \mathrm{p} .12]$.

It follows that there is merit in the exercise of police discretion to divert young offenders away from proceedings which, no matter how informally they may be conducted, continue to be 'criminal' $[64,71 ;$ p.12].

The juvenile liaison scheme can be traced back to the practice of oral police cautioning of young offenders for relatively trivial offences. When a police officer administered a caution he would usually follow it up by keeping in touch with the young person, and by enlisting the co-operation of his family, his school and relevant statutory and voluntary social services with a view to diverting him away from offending in the future [51; para.139]. The scheme itself was initiated in these islands as a result of a special request from the chief education officer of the borough of Liverpool (England) in 1952 and continued as a police service of home visitation in response to requests from parents and headmasters [36]. ${ }^{2}$

\footnotetext{
2 "As the police desire to share in the treatment reaction to crime grew, there developed first in the United States the idea that individual police departments should undertake some form of delinquency prevention and treatment. The development, in 1925, of the Berkeley, California, Police Department's
} 
Cautioning was first introduced to Ireland in 1953 [56]. Ten years later, following the visit (of a month) by two members of An Garda Siochana to Liverpool [56], the juvenile liaison scheme was commenced. Initially, it was confined to the Dublin Metropolitan Area, and was not launched nationwide until 1981 [2; para.4.1]. In 1991, it was supported by the establishment of the Garda National Juvenile Office, and its remit was extended to juveniles up to 18 years of age and a wider range of offences [66; p.24]. Nevertheless, it continued to operate on a purely administrative, as distinct from a statutory, basis. Its function was focused on preventing a court appearance for the majority of first offenders and sought to divert them from the path of criminality. Under the scheme, an offender who came into contact with the police for an eligible offence was released, provided that he had not previously come to the attention of the police, he admitted the offence or accepted responsibility for it and the injured party indicated no objection to him being cautioned. No decision was taken at this point as to the offender's ultimate disposition. The Juvenile Liaison Officer would make a recommendation after assessing the young person's suitability for caution and determining his home condition and his schoolteacher's opinion. The primary options were an informal caution, a formal caution and a prosecution. The recommended disposition made its way up the hierarchical police structure to a chief superintendent who made the final decision. Shanley explained that this "stay of execution" afforded the officer an opportunity to view the case more objectively, thereby reducing the "effects of the prejudices and impressionistic judgments" which can affect the manner of disposition made at the initial encounter between the police officer and the offending youth [56].

Some fourteen years after its inception, a total of 11,413 juvenile offenders had been cautioned, despite the scheme not operating country wide [10; p.24]. In other areas a more informal type of supervision was applied by local Gardaí. A two year study in the early 1970's found that participants in the scheme had a lower than normal rate of recidivism, except in Limerick, and that appearances in the Dublin Metropolitan Children's Court were reduced by $22 \%$ for boys and by $32 \%$ for girls in the first year of its operation $[31 ;$ p.13]. The introduction of the scheme also coincided with a

Crime Prevention Division can probably be considered as the forerunner of most present day police activities in this area." [5; p.404]. 
reduction in the number of cases dismissed under the Probation of Offenders Act 1907. Critically, it would appear that the operation of the scheme was heavily coloured by Garda discretion, which Shanley noted was the 'hallmark of the system of formal cautioning in both England and Ireland.'[56] In some areas very few first offenders were admitted, while in others all first offenders were admitted. It was a matter for the police to decide whether an individual offender was referred to the scheme or not. It is important to note, however, that this exercise of discretion was not confined to the decision on whether to initiate the criminal process. It also entailed decisions on the form of punishment or treatment to be applied in circumstances for which there was no legal sanction [5].

Indeed, concerns were expressed that the scheme allowed the police to set themselves up as prosecutor, judge and executioner of the sentence imposed, thereby removing from the offender all the protection and rights afforded by the courts of justice $?^{3}$ The operation of scheme lacked any legal basis or independent mechanism to examine what police policies and procedural guidelines if any applied. Despite its introduction, the police were still able to act more or less as autonomous agents within the criminal justice system, shielded from effective accountability for their disposition of young offenders. Furthermore the scheme did not prevent police officers from acting outside its provisions as they could continue to exercise, without accountability, the street level discretion that they had enjoyed before the scheme was introduced.

\section{The Diversion Programme}

It took until 2001 before the juvenile liaison scheme was placed on a statutory basis under the designation of the Diversion Programme [12; pt.4]. As Walsh remarks, this was a positive feature from a due process perspective as it meant that the Programme would operate officially in accordance with the law $[67 ;$ p.6]. On the other hand, there is reason to believe that it continues to function in many respects along the lines of the administrative scheme which it replaced. The Programme's objective is to divert from further offending children, who have accepted responsibility for their criminal behaviour [12; s 19(1)]. This is achieved primarily by way of caution and, where appropriate, by placing the offender under the supervision of a juvenile liaison officer

\footnotetext{
${ }^{3}$ The comments of a senior probation officer in a discussion held in London in 1959 as quoted in [36; p.364].
} 
and the convening of a restorative conference to be attended by the child, members of his family and other relevant persons to discuss the child's offending and circumstances and how they might best be addressed [12; s 19(2)]. Despite these additional elements and a number of procedural changes, the new Programme continues to be dominated by police discretion. Indeed, as Kilkelly remarks, what evolves from this new Programme is a process entirely under the control of the police acting in an exclusive role separate from judges or other independent officials acting in a judicial capacity [33; pp.83-84]. This permits justice to be conducted under a cloak of secrecy and reflects a major departure from due process norms. The question arises again whether there are sufficient checks and balances to ensure transparency and accountability over the policies and procedures employed by the police in the Programme.

In 2009 , there were 18,519 referrals for inclusion into the programme, and $76 \%$ were admitted. Of those admitted, 54\% were dealt with informally, $21 \%$ were dealt with formally, $16 \%$ were deemed unsuitable, in $6 \%$ no further action was deemed necessary, and 3\% were still pending at the end of the year [3]. While the figures reflect a decrease of $14 \%$ on the referrals for 2008 , the percentages of admissions and dispositions do not show any significant changes, apart from a slight drop in the administration of formal cautions and a slight increase in the figure for no further action. More importantly, neither the figures nor the associated commentary on them from sources such as the Committee to Monitor the Effectiveness of the Diversion Programme shed much light on the factors that determine the selection of one mode of disposition over another; especially the factors that are deemed to render a child unsuitable or not in need of any further action.

It is the Director of the Programme who determines eligibility for entry into the programme. Significantly, she is and, by statute, must be a police officer. However, neither the legislation nor the Director provides transparent criteria that are used to base the decision to apply one disposition as opposed to another in any individual case. The net effect is that the Director is left with a very broad discretion in her administration of the Programme, and she is exercising that discretion in a manner that precludes effective accountability. In the absence of detailed published criteria on the dispositions, there is no basis on which decisions in individual cases or internal 
policies can be questioned externally. This creates a scenario in which the police can 'cherry pick' the offenders who are most likely not to re-offend, and abandon the lesser prospects to trial in the criminal courts. Should this happen in practice, the consequence is that the figures on subsequent recidivism among offenders admitted to the Programme would falsely exaggerate its success. The Programme also lends itself to 'net-widening' of social control by the police $\left[9,16,18,38 ;\right.$ p.166]. ${ }^{4}$ In the absence of viable accountability checks and balances, the police can use their discretion to rein in minor 'offenders' who would have been ignored or 'let off' in the past. This also enhances the risk of arbitrary discrimination against certain individuals and classes.

Ultimately, it can be argued that there is a serious mismatch between the objective of the Programme to divert young offenders from the path of criminality, and anything that can realistically be achieved within the limits of the traditional police role. The proper discharge of the Programme's objective would require the police to combine quasi-judicial and social welfare roles with their traditional law enforcement functions. Inevitably, this entails an expansion and deepening of police discretion, with major consequential risks for the welfare and due process rights of the children concerned. Admittedly these risks could be minimised or reasonably managed if the exercise of that discretion was subject to transparent and effective accountability mechanisms. The Programme, however, is established in a manner that leaves excessive operational discretion in the hands of the police. Moreover, it would appear that it is managed by the police in a manner that maximises the scope and depth of their role in the treatment of young offenders, and minimises the scope for external accountability. This can be illustrated by reference to a few key aspects of the Programme.

\section{Discretion to choose between diversion and prosecution}

The diversion of juvenile offenders from formal court proceedings is generally rooted in a 'welfare' based system of juvenile justice. This aims at developing the child's treatment according to his/her response and changing needs, in contrast with the

\footnotetext{
${ }^{4}$ Net widening is a term most commonly used to describe a phenomenon whereby a program is set up to divert youth away from an institutional placement or some other type of juvenile court disposition but, instead, merely brings more youth into the juvenile justice system who previously would never have entered. Instead of shrinking the "net" of social control, one actually "widens" it to bring more in.
} 
'justice' based system which provides for intervention and sanctions proportional to the nature of the offence, even where, as is often the case with juveniles, the offending is minor. Indeed, Cohen argues that "diversion becomes not movement out of the system but movement into a programme in another part of the system" [13]. Despite the ongoing tug of war between the proponents of both systems there is agreement that diversion by means of police caution can be a desirable objective [60].

Although diversion is intended to keep an offender out of court, it still entails an element of quasi-judicial decision-making on how he will be dealt with in respect of his offending [12; pt 4]. The decision-making role, however, is discharged by a police officer rather than a judge. Critically, police officers are entrusted with discretionary powers that distinguish them from all other players in the criminal justice system [21, 70]. This is most evident in the context of the diversionary scheme where, unlike judges and prosecutors, they exercise their discretionary powers at street level out of the purview of public scrutiny. Furthermore without the burden of due process, and subject to no review, an individual police officer can effectively acquit an offender by exercising his discretion discreetly, through informal action such as a caution or even ignoring an offence entirely. In other words, he or she has the power selectively to pre-empt the entire course of a criminal prosecution [70]. The capacity for such discriminatory enforcement of the law permits the police to redefine justice in their own interests and concerns, and that might not necessarily be consistent with the priorities of the wider community [22, 47].

Police discretion can also be viewed as a usurpation of the legislative authority of that community and their elected representatives. If there are laws that the community actually want enforced with discretion then there is no reason why provision for that cannot be made by their duly elected representatives in the legislature [47].

Responsibility for the enactment, amendment, and repeal of the criminal law will not then be abandoned to the whim of each police officer or department, but retained where it belongs in a democracy-with elected representatives [24]. In practice, police officers exercise a wide range of discretion and power over who will be subject to legal intervention and social control. Given the fact that such decisions are made on the street, "methodological problems are considerable and frequently the subject of criticism" [20]. They do not in the main involve recording and are seldom subject to accountability, as the police officers invariably work 
beyond the reach of direct supervision. It is difficult to account properly for the actions of each individual in his or her contacts with young offenders. Informal street encounters leave no information records on which the basis for a discretionary police decision can be reviewed; a decision which could have lasting consequences for the youth concerned. Consistency and objectivity in the exercise of such discretion requires transparent and detailed police policies and procedures to guide the officers concerned. The absence of guidance facilitates arbitrary police discrimination in the determination of who will or will not be subject to prosecution. In this context, the development of the statutory Diversion Programme held out the potential for objective and transparent criteria to control the exercise of the police discretion guide. Unfortunately the opportunity was not taken in the legislative framework for the Programme and has not been taken since in its management.

\section{Precondition of admitting guilt}

A fundamental principle underpinning the Diversion Programme is the offender's admission of guilt or acceptance of responsibility for the offence. In the absence of this admission, the offender will be excluded from the Programme and routed through a prosecution and court appearance. This procedural requirement for a guilty plea affords the police an opportunity to override the fundamental principles of justice by usurping the jurisdiction of the court and denying the due process rights of the offender. It effectively relinquishes his option to avail of a fair trial, the presumption of innocence and having the prosecution prove the case beyond a reasonable doubt. It creates a situation whereby the police officer can manipulate or cajole the offending child into admitting guilt or risk prosecution even in circumstances where the officer has little or no evidence on which to base a prosecution [47]. Additionally, the fear of a court appearance could also be used as an intimidating or inducing tool by the police to obtain an admission of guilt [69]. Indeed, it is not unreasonable to suggest that the admission of guilt could be viewed by the parents of the young offender as a 'get out clause' to prevent what they may consider an embarrassing or shameful appearance in court despite a situation where their child might be completely innocent. Conversely, however, there are some parents who might prefer the short, sharp shock of a court appearance rather than the protracted participation in the Programme which entails home and school visits by the police. In other words, the objection is not to the caution, but to the procedure within the scheme which follows the caution. 
In principle, of course, police discretion to recommend the caution of a juvenile offender should not be exercised as a substitute for a weak prosecution case. The available evidence must be sufficient to warrant a prosecution on the basis that a conviction is more likely than an acquittal. There is a danger, however, that the police will fail to apply appropriate unwritten legal criteria in practice as they frequently view the caution as a 'let-off'.

This aspect of the Programme signals a significant departure from due process norms, even though its likely consequences are that the offending youth will be subjected to constraints on his freedom and autonomy that can exceed those that would have applied in the formal criminal process [67]. The "welfare trade off" is that youth does not have to suffer the experience of that formal criminal process and is given support to avoid retuning to the path of criminality [67]. It should be feasible, however, to preserve the advantages of the Programme within a regime that is more conducive to due process and transparency [33]. This might be achieved, for example, through the formulation and publication of criteria governing admission to, and other pivotal decisions within, the Programme, together with the publication of comprehensive information on the extent to which the scheme is diverting children away from crime [67]. These policies should reflect the international standards on juvenile justice which prioritise both the observance of due process and the best interest of the child [62; arts 3(1) and 40(2), 63; r 7].

It is unlikely that the promulgation of statutory and administrative criteria will be sufficient in itself to protect the due process rights of the child offender and ensure transparency and fairness in the operation of the Diversion Programme. As Dixon points out, the relationship between policing and legal rules is seldom straightforward [15]. The use of rules can be problematic in any context because of "their tendency towards over- or under-inclusiveness, their indeterminacy, and their interpretation" [8; p.6]. Rules by nature have an 'open texture' because rule makers cannot anticipate all possible future events and circumstances to which the rules apply [8; p.11]. Hawkins sees discretion as central to the legal order since "the complexity of contemporary society, the sheer size and burden of the legislative task, and the growing dependence upon specialist, technical, or scientific knowledge and expertise' have meant that 
legal systems must rely on legal and administrative officials to give effect to the law [27; p.12]. Discretion is also an integral part of interpreting legal rules, which are never unambiguously and precisely written. On the other hand, the difficulty with discretion is the propensity for the police to depart from the unwritten principles and standards associated with legality, e.g., consistency, equity, proportionality, due process and justice. The task, therefore, is to subject the exercise of police discretion in the Programme to effective accountability mechanisms which deliver transparency and the opportunity to challenge decisions in individual cases.

\section{Trespassing on the judicial function}

As noted earlier, prior to 1908 the police were reluctant to prosecute children though the courts, given the risks inherent in a criminal record and exposure to hardened criminals. The establishment of the juvenile court in 1908 went some way towards redressing these fears by establishing a separate court for dealing with the juvenile offender. Given this option, it is not wholly clear why the police would still opt not to prosecute. Indeed the Departmental Committee on the Treatment of Young Offenders found the use of informal warnings to be objectionable "usurping the functions of a tribunal" and "outside the proper duties of the police" [23; p.30]. The juvenile court provided independent and transparent procedural justice which was subject to public scrutiny, elements notably absent from discretionary police cautions. With this option available within the criminal justice system, what need if any did police have to resort to an oral caution or the juvenile liaison scheme to deal with juvenile offenders?

At least part of the answer is that the juvenile court was not always the most appropriate option. It still followed a procedure that was highly formal and legalistic and it was not bound to take into account the juvenile's welfare [52; p.70]. Equally, however, it would appear that the police did not always have confidence in the court. Whitaker suggests that the system of oral cautioning coupled with juvenile liaison schemes had found favour with the police "partly because of dislike of the delays of the juvenile courts" [68; p.85]. It has also been suggested that some police officers thought that the attitude of the court was too "soft" [43; p.424]. In their view, this had the effect of familiarising the deviant youth gradually with the "not too unpleasant experience of a court appearance", and a consequent propensity to undermine the authority of the court [26; p.70]. On the other hand, there is undoubtedly merit in the 
police, or some other agency, operating as a filtering mechanism to sift out those cases which really need to be dealt with by a court because of factors such: as the gravity of the offence in question, the need to uphold the due process rights of the child, and the need for specialised treatment that can best be accessed through the medium of the court. The sifting mechanism will enable the court to focus its limited time and resources on those cases most suited to its distinctive role, while the others can be routed through alternative remedial processes.

A reform on these lines would assign to the courts those cases where a judicial decision is expected and required, but would spare from appearance in court many of those against whom at present the court itself thinks best to take no action [26; p.128].

The problem is that the police have managed to occupy the field of the sifting mechanism. They have usurped the key quasi-judicial function of determining whether a young offender should be dealt with by the courts or through a non-judicial remedial process, despite the fact that the latter usually takes the form of a caution and ongoing intervention under the control of the police themselves. Not only does this present a clear conflict of interest, but it sucks the police into a role that is more properly associated with the court. Unlike the court, however, the police decisionmaking in this area lacks transparency and accountability as the final disposition in any individual case is not made by an independent adjudicator and is not subject to public scrutiny.

\section{Trespassing on the welfare function}

There are several aspects of the Diversion Programme which entail police officers discharging the welfare role of social workers and probation officers. The juvenile liaison officer, for example typically will make a home visit prior to the disposition of the case. This will allow him or her to make an assessment of the potential of parents for controlling the future behaviour of the child as well as the juvenile himself and the circumstances surrounding the infringement. It is questionable whether this should be the role of the police or the function of professional trained social workers. Such visits effectively represent an encroachment by the police into the area of welfare which, arguably, is outside the remit of a law enforcement agency. It is important to preserve the distinction between policing and social work. Police training is orientated towards crime and punishment not welfare [61; p.103]. Indeed the liaison officer is first and 
foremost a police officer and, as such, his primary allegiance is to the police organisation rather than the welfare of the juvenile offender. Uglow makes the point that while the social worker invades the youth's privacy he "identifies more closely the interest and welfare" of the juvenile offender and the invasion is not as threatening as that of the police [61; p.103].

The inherently different perspectives can result in subjective discrimination against young offenders from certain social backgrounds. Home visits to offenders from a lower socio economic background, for example, might steer police discretion against informal cautions as the law enforcement officer might be more inclined to view the home circumstances as not conducive to a modification of the offending behaviour. School visits by police officers to obtain the teacher's opinion of the child also present problems. The police officer's role in school visits should be confined to their area of expertise; namely to promote understanding of and respect for the law and the fostering of good relations between the police and young people. Probing the complex psychological, behavioural, learning or domestic problems of a child offender does not come within that remit. These aspects should be left to those professionals who are specially trained to deal with them.

A further example of the police trespassing into the welfare function arises at the supervisory stage of the Programme where the juvenile liaison officer assumes the expertise of a Probation officer. This occurs when the young offender has been the subject of a formal caution. The supervisory period lasts for 12 months from the date of the caution $[12 ; \mathrm{s} .27(1)] .^{5}$ The level of supervision is determined by the juvenile liaison officer who is supervising the child having regard to such factors as the seriousness of the criminal behaviour, the level of control by the parents, the likelihood of committing further offences or where the Director considers it appropriate [12; s.28]. There is an argument for incorporating this role under the auspices of the probation system and removing it from the police Diversion Programme. The advantages of the probation option are succinctly outlined by James O'Connor:

\footnotetext{
${ }^{5}$ In exceptional circumstances an offender may be subject to supervision for a period of 6 months following an informal caution.
} 
The probation system is a valuable means of reforming an offender and has a unique feature that the accused person may continue as a member of the community, remaining at school or at his work. There is the further advantage that the responsibility of reforming an offender is not that of an institution, but rests with the offender himself. He must keep up a standard of good conduct and obey the conditions of the probation order, and, since this will be all the harder to do outside an institution than within, if he succeeds his reformation will almost certainly be all the more successful and permanent. [42; p.75]

The aims of the probation system are fundamentally similar to those of the supervisory role within the Diversion Programme in that they seek to reform the offender by dealing with him as a member of the community rather than in an institution in the belief he can be successfully and permanently diverted from a life of crime. It does not follow, however, that police training is suitable or appropriate for this challenge:

Young offenders were often of extremely low intelligence or emotionally maladjusted: police officers, however good their intentions: lacked the special training necessary to help those who suffered from such handicaps. Trivial offences were often only a symptom of an underlying condition, requiring early and specialised treatment, that was revealed only by the full inquires made when the child came before a court [51; para.146].

\section{Conclusion}

The Garda role in diverting young offenders away from the formal criminal process is, and always has been, inextricably linked with the discretion that they bring to bear in the detection, prevention and prosecution of crime. They have used this imaginatively to expand their traditional law enforcement competence in juvenile justice to encompass judicial and welfare functions normally discharged by separate specialist agencies. Critically they have managed to do this while avoiding many of the checks and balances applicable to those agencies. Arguably, they have used their discretion to establish and maintain a parallel criminal justice process for young offenders which operates beneath the radar of transparency and objectivity applicable to the formal criminal process. Part of the problem with such police discretion is that it is prone to being used in ways that discriminate (in effect, if not in intent) against the poor, powerless, and unpopular in our society [46, 48; pp.106-110]. ${ }^{6}$ This can undermine the 'legitimacy of the law where it is most in need of legitimacy' [47]. Although discretion is an inevitable part of policing, it becomes problematic where it

\footnotetext{
${ }^{6}$ For a general overview of the problem and recent attempts to solve it, see [65; ch.2].
} 
is exercised in a manner that lacks consistency and fairness. [44]. It does happen that police officers behave differently in similar situations; some willing to take no action towards a young offender while others would arrest the same offended regardless of the nature of the offence [44]. To promote consistency and fairness in police decision making, policies and procedures must be in place to provide guidance to individual officers on the appropriate use of their discretionary powers.

The establishment of the Diversion Programme on a statutory basis offered the potential to inject a much needed degree of transparency and accountability into the discharge of the Garda juvenile justice role. It was reasonable to expect that the legislation would introduce greater clarity into the demarcation of the police, judicial and welfare remits. Equally it could and should have injected more transparency to the operation of the Programme and more effective accountability for the manner in which discretion is exercised in individual cases and across the Programme as a whole. Unfortunately, the legislation has done little to fulfil these expectations. Nor has the Garda management of the Programme done all that it could do to inject greater transparency and accountability into it. While there have been some improvements in the publication of information and data, these still fall short of what is required. It may be, of course, that the provision of internal checks and balances within the police management of the Programme will prove incapable of overcoming the 'cop culture' pressures on officers to support each other's decision [4, 49, 53]. Ultimately, there may be a need to introduce an element of external oversight. 


\section{References}

1. Adams, M.S., Robertson, C.T., Gray-Ray. P., \& Ray, M.C. (2003). Labelling and Delinquency, Adolescence, 38, 149.

2. Annual Report of the Committee Appointed to Monitor the Effectiveness of the Diversion Programme. (2004). Dublin: Department of Justice, Equality and Law Reform

3. Annual Report of the Committee Appointed to Monitor the Effectiveness of the Diversion Programme. (2010). Dublin: Department of Justice, Equality and Law Reform.

4. Ashworth, A. (1998). The Criminal Process An Evaluative Study. Oxford: Oxford University Press.

5. Barker, B.M., (1965-1966). Police Discretion and the Principle of Legality The Criminal Law Quarterly, 8, 400-407.

6. Becker, H. (1963). Outsiders: Studies in the Sociology of Deviance. New York: Free Press.

7. Bernburg, J.G., \& Krohan, M.D. (2003). Labelling, Life Chances, and Adult Crime: The Direct and Indirect Effects of Official Intervention in Adolescence on Crime in Early Adulthood, Criminology, 41(4), 1287-1318.

8. Black J. (1997). Rules and Regulations. Oxford: Clarendon.

9. Blomberg, T. (1980). Widening the Net: An Anomaly in the Evaluation of Diversion Programs. In Klein, M., \& Tielman, K. (eds.). Handbook of Criminal Justice Evaluation. Beverly Hills, CA: Sage Publications, 571.

10. Burke, H., Carney, C., \& Cook, G. (1981). Youth and Justice: Young Offenders in Ireland. Dublin: Social Administration Institute.

11. Carrington, P.J., \& Moyer, S. (1994). Trends in Youth Crime and Police Response, Pre-and Post-YOA Canadian Journal of Criminology, 36(1) 1-28.

12. Children Act, 2001.

13. Cohen, S. (1979). Community Control- A New Utopia. New Society, 609-611.

14. Ditton, J. (1979). Contrology: Beyond the New Criminology. London: Macmillan.

15. Dixon. D. (1997). Law in Policing Regulations and Police Practices. Oxford: Clarendon.

16. Dunford, F. W. (1977). Police Diversion: An Illusion? Criminology, 15(3), 335-352.

17. Emsley, C. (1983). Policing and its Context 1750-1870. London: Macmillan.

18. Ezell, M. (1989). Juvenile Arbitration: Net Widening and Other Unintended Consequences Journal of Research in Crime and Delinquency, 26(4).

19. Figueira-McDonough, J. (1979). Processing Juvenile Delinquency in Two Cities: A Cross-National Comparison. Journal of Research in Crime \& Delinquency, 16(1), 114-143.

20. Fisher, C. J., \& Mawby R.I. (1982). Juvenile Delinquency and Police Discretion in the Inner -City Area. British Journal of Criminology, 22(1), 6375.

21. Gandy, J.M. (1970). The Exercise of Discretion by the Police as a Decision Making Process in the Disposition of Juvenile Offenders. Osgoode Law Journal, 8(2), 339-344. 
22. Garrett, M., \& Short, J.F.jnr. (1975). Social Class and Delinquency:

Predictions and Outcomes of Police -Juvenile Encounters. Social Problems, 22, 132-142.

23. Gelsthorpe, L., \& Kemp, V. (2003). Youth Justice: Discretion in Pre-Court Decision Making. In Gelsthorpe, L., \& Padfield, N. (2003). Exercising Discretion Decision-Making in the Criminal Justice System and Beyond. Cullompton: Willan Publishing. 30.

24. Goldstein, J. (1960). Police Discretion Not to Invoke the Criminal Process: Low Visibility Decisions in the Administration of Justice. Yale Law Journal, 69(4), 543.

25. Griffin, D. (2005). Restorative Justice, Diversion and Social Control: Potential Problems. National Conference on Young People and Crime Research, Policy and Practice. Dublin: Centre for Social and Education Research.

26. Grunhut, M. (1956). Juvenile Offenders Before the Courts. Oxford: Oxford University Press.

27. Hawkins, K. (1992). The Use of Legal Discretion: Perspectives from Law and Social Science. In Hawkins, K (ed.). The Uses of Discretion. Oxford: Clarendon. 11-46.

28. Hoyle, C., \& Young, R. (2003). Restorative Justice, Victims, and the Police. In Newburn, T. (ed.). Handbook of Policing. Cullompton: Willan Publishing, 680 .

29. Hirschfield, P.J. (2008). The Declining Significance of Delinquent Labels in Disadvantaged Urban Communities. Sociological Forum, 23(3), 575-601.

30. Inniss I., \& Feagin, J. (1989). The Black "Underclass" Ideology in Race Relations Analysis. Social Justice, 16(4), 13-34.

31. Irish Times (13 ${ }^{\text {th }}$ May 1975).

32. Jones, H. (1963). Policemen as Social Workers. New Society, 14, 9-11

33. Kilkelly, U. (2006). Youth Justice in Ireland: Tough Lives, Rough Justice. Dublin: Irish Academic Press.

34. Lemert, E. (1967). Human Deviance. Social Problems and Social Control. Englewood Cliffs, NJ: Prentice Hall.

35. Lindsey, B.B. (1905). The Boy and the Court. Charities, 13(7), 350-357.

36. Mack J.A. (1962-1963). Police Juvenile Liaison Scheme. British Journal of Criminology, 3, 361-375.

37. Magarey, S. (1978). The Invention of Juvenile Delinquency in Early Nineteenth-Century England. Labour History, 34, 11-25.

38. Maxwell, G., \& Morris, A. (1993). Family Victims Culture, Youth Justice in New Zealand. Wellington: Social Policy Agency and Institute of Criminology, University of Wellington. 169.

39. May, M. (2002). Innocence and Experience: The Evolution of the Concept of Juvenile Delinquency in the Mid-Nineteenth Century. In, Muncie, J., Hughes, G., \& McLaughlin, E. Youth Justice, Critical Readings. London: (Sage Publications, 98.

40. Metropolitan Police Act 1938, $2 \& 3$ Vict. C.47.

41. Nowak, B.J. (1994). Variables Impacting the Discretionary Decisions made by Juvenile Court Gatekeepers. Dissertation Abstracts International Section A: Humanities and Social Sciences, (0419-4209), 54, 2746.

42. O’Connor, J. (1963), The Juvenile Offender. Studies: an Irish Quarterly Review, 52, 69-86. 
43. Osborough, N. (1965). Police Discretion not to Prosecute Juveniles. Modern Law Review, 28(4), 421-431.

44. Parkert A.L., \& Sarre, R. (2008). Policing Young Offenders: What Role Discretion? International Journal of Police Science \& Management, 10(4), 474-485.

45. Pearson, G. (1983). Hooligan: A History of Respectable Fears. London: Macmillan.

46. Powell, D.D. (1990). A Study of Police Discretion in Six Southern Cities. Journal of Police Science and Administration, 17(1), 1-7.

47. Reiman, J. (1998). Against Police Discretion: Reply to John Kleinig. Journal of Social Philosophy, 29(1), 132-142.

48. Reiman, J. (ed.). (1998). The Rich Get Richer and the Poor Get Prison: Ideology, Class, and Criminal Justice. Needham, Mass: Allyn \&Bacon.

49. Reiner, R. $3^{\text {rd }}$ ed. (2000). The Politics of the Police. Hemel Hempstead: Wheatsheaf.

50. Report of the Committee of Inquiry into the Penal System (Whitaker Report). (1985). Dublin: Stationery Office.

51. Report of the Committee on Children and Young Persons. (1960). London: Home Office, Cmnd.1191.

52. Report on the Industrial and Reformatory School System (Kennedy Report). (1970). Dublin: Stationery Office.

53. Sanders, A. (1998). The Limits to Diversion from Prosecution. British Journal of Criminology, 28(4), 513-532.

54. Sarre, R. (2005). Police and the Public: Some Observations on Policing and Indigenous Australians. Current Issues in Criminal Justice, 17(2), 305-313.

55. Schissel, B. (2002). Youth Crime, Youth Justice and the Politics of Marginalization. In Schissel, B., \& Brooks, C. (2002). Marginality and Condemnation: An Introduction to Critical Criminology. Halifax: Fernwood Publishing.

56. Shanley, P. (1970). The Formal Cautioning of Juvenile Offenders. The Irish Jurist, 5, 262-279

57. Simpson, J. (1968). The Police and Juvenile Delinquency. British Journal of Criminology, 8, 119-129.

58. Steer, D. (1970). Police Cautioning - a Study in the Exercise of Police Discretion. Oxford: Basil Blackwell.

59. Tannenbaum, F. (1938). Crime and Community. Boston: Ginn.

60. Tutt, N. \& Giller, H. (1983). Police Cautioning of Juveniles: The Practice of Diversity. Criminal Law Review, 585-595.

61. Uglow, S. (1988). Policing Liberal Society. Oxford New York: Oxford University Press.

62. United Nations Convention on the Rights of the Child 1989.

63. United Nations General Assembly. (1985). Standard Minimum Rules for the Administration of Juvenile Justice. New York: United Nations.

64. United National General Assembly. (1990) Riyadh Guidelines for the Prevention of Delinquency. New York: United Nations.

65. Walker, S. (1993). Taming the System: The Control of Discretion in Criminal Justice, 1950-1990. New York: Oxford University Press.

66. Walsh, D.P.J. (2005). Juvenile Justice. Dublin: Thomson Round Hall. 
67. Walsh, D.P.J. (2008). Balancing Due Process Values with Welfare Objectives in Juvenile Justice Procedure: Some Strengths and Weaknesses in the Irish Approach. Youth Studies Ireland, 3, 3-17.

68. Whitaker, B. (1964). The Police. Harmondsworth: Penguin Books.

69. Wolcott, D. (2001). The Cop Will Get You: The Police and Discretionary Juvenile Justice 1890-1940. Journal of Social History, 35(2), 349-371.

70. Wortley, R.K. (2003). Measuring Police Attitudes Toward Discretion. Criminal Justice and Behaviour, 30(5), 538-595.

71. Young Offenders: White Paper. (1980). London: HMSO.

72. Zimring, F.E. (2000). The Common Thread: Diversion in Juvenile Justice. California Law Review, 88(6), 2477-2495.

73. Zaitsev, G.K., Zaitsev, A.G., Dmitriev, M.G., \& Apal'kova, I.I. (2009) "Rehabilitation of the Personality of Juvenile Offenders. Russian Education and Society, 51(11), 50-60. 